\title{
GLL
}

a

Geomatics, Landmanagement and Landscape No. $2 \cdot 2019,135-152$

\section{UNAMBIGUOUS DETERMINATION OF POINT COORDINATES IN THE GEODETIC MEASUREMENT NETWORK WHEN ESTABLISHING LAND RECORDS}

\author{
Mateusz Śmigielski, Jacek M. Pijanowski, Jacek Gniadek
}

\begin{abstract}
Summary
The article discusses the problem of unambiguous determination of the geodetic control network points' coordinates in the State Geodetic Coordinate System 2000, fixed during works related to the establishment of land records. The solutions and measurement methods applied in this respect, in accordance with the applicable standards, in many cases do not allow the correct identification of the boundary points of land plots in the process of their designation. The data provided by the district centres of surveying and cartographic documentation (PODGiK) concerning the point coordinates of measurement networks established for the purpose of creating land records in the period following World War II present a lot of problems for geodetic contractors. Due to the lack of unambiguous coordinates of the geodetic network points, undertaking additional work is often required, including the identification of geodetic network points and verifying the compliance of their position in the field, based on the archival data. These are time-consuming activities, and they do not always bring the intended effect. The present article contains the results of the research on the compliance of archival data with the actual location of points in geodetic networks, in several selected precincts of the Świętokrzyskie region. On the basis of the analyses we have carried out, discrepancies were determined within the data constituting the PODGiK resources, and a solution was proposed to obtain coordinates of geodetic network points that could be considered correct.
\end{abstract}

\section{Keywords}

geodetic network • 1942 coordinate system • 1965 coordinate system • 2000 coordinate system - establishing land records $\bullet$ determination of boundary points

\section{Introduction}

In the lands of the former Russian partition, which included the area of the present Swiętokrzyskie region, there existed no uniform cadastre, unlike in the lands under the Prussian or Austrian partitions [Wilkowski 2005, Hanus 2007]. Only one part of the Russian-occupied land was covered by the so-called Zamojski Cadastre [Cymerman et 
al. 1987, Wolski 2001, Hycner 2004]. In the interwar period, no works were conducted that would aim to establish a cadastre for all the lands of the aforementioned area. Only maps for particular plots and consolidated land were drafted as part of the implemented agricultural reform [Resolution 1919]. After 1955, in areas for which no cadastral maps were prepared or where the existing maps did not meet the accuracy requirements, measurements were made directly in the field, based on the assumed geodetic network [Instruction BIII]. The boundaries of use - that is, margins and fences visible in the land, which determined the current state of ownership - were subject to measurement. The established geodetic networks were fixed in the field in a permanent manner [Frelek 1965]. The coordinates of the geodetic network points were calculated in the local 1942 coordinate system ${ }^{1}$, or in the 1965 coordinate system ${ }^{2}$.

At present, in the Świętokrzyskie region, there are major difficulties when developing documentation for legal purposes. Contractors of geodetic works encounter many problems resulting from the lack of proper coordinates of archival points of geodetic measurement networks. The difficulties that occur during their implementation concern the following cases:

a) Some of the coordinates of the points had been transformed into the State Land Surveying System $2000^{3}$ (PL-2000, hereinafter: the 2000 layout) - it happens that the same points on the boundary border have different coordinates.

b) In the areas where the coordinates of points in the geodetic measurement network are missing (only the observation records are kept in the documentation) or the coordinates are given in the local system - it is problematic to identify is markings in the field.

c) Some of the markings have not been preserved, some have been damaged or shifted - there is a problem of linking such geodetic networks to the currently binding coordinate system (the 2000 layout).

When calculating the coordinates of breakpoints (corners) of the boundaries of plots, the contractors often adopt the coordinates in the 2000 layout received from PODGiK as correct, or they measure the found points, changing the coordinates to the current ones - corresponding to the location of the markings. However, it is not certain whether the found and the measured point, whose coordinates differ from those obtained from PODGiK, had been assigned incorrect coordinates, or whether the point itself had been shifted over the years.

1 Historical layout, not belonging to the state system of spatial reference according to the Regulation [2012] on the state system of spatial reference. The layout was introduced in 1953 [Law of 1953]. The layout has been classified, and coordinates were removed from the archive documents, leaving only the notes of field observations.

2 State Land Surveying System 1965 - layout of plane coordinates in conformal projection, used for the maps in the scale of $1: 5000$ and larger (base map). The 1965 layout remained in force until 24 August 2000 (source: https://pl.wikipedia.org/wiki/Uk\%C5\%82ad_wsp\%C3\%B3\%C5\%82rz\%C4\% 99dnych_1965).

3 Regulation [2012] by the Council of Ministers on the state system of spatial reference. 
In cases where there are no coordinates, or if the coordinates were defined in the local system, it is necessary to link the measurement network in the field to the 2000 layout. Measurements and calculations (transformations) made for a small number of geodetic network points, which are necessary for calculating the coordinates of the plot's corners, are not the correct solution, because the computed coordinates of boundary points remain ambiguous when calculated in this way. Often a situation occurs when certain coordinates for a common boundary section of neighbouring plots, calculated by different contractors, deviate significantly from each other.

Therefore, it seems necessary to implement solutions that will make it possible to correct erroneous data in the PODGiK resources in such a way that their continued use by geodetic contractors would not cause problems, and that the data resulting from the new measurements would be appropriate and consistent.

\section{Objective and scope of the paper}

The objective of this paper is to present problems occurring when calculating the coordinates of boundary points of plots measured during the establishment of land records, which result from an ambiguous determination of the coordinates of the points in the geodetic measurement network. The research was carried out in the Ciecierze and Radlin sections located in the Świętokrzyskie region. The detailed analysis concerned the comparison of the point coordinates of selected measuring networks existing in the PODGiK resource with the results obtained on the basis of the direct measurement of these points with the use of archival data. The obtained result allowed us to estimate the scale of discrepancies between the output data and those obtained based on the new measurement. The obtained test results led us to propose a methodology that can contribute to the unambiguous determination of the coordinates of the existing points in the 2000 system.

\section{Outline of land records development in the Świętokrzyskie region}

The beginnings of the cadastre on the territories of the Russian partition are connected with the publication of the Tsar's order of 1864 titled "On the appropriation of peasants" [Order 1864]. Documents created on the basis of the Order were liquidation tables and conferment tables constituting legal proof of ownership. These were prepared for each village cluster separately. Conferments were not accompanied by measurements - data in the tables concerning the area size were given indicatively. The measurements were carried out later. In the course of the measurements, the principles of the Polish "Instruction for the measurement of the area of public domains and forests" from 1839 were used. The next binding law was the "Codified Laws of 9 April 1881 on the Measurement and Demarcation of Lands Regained to the Property of the Governors of the Kingdom of Poland for of the most important orders of February 19, 1864" [Mika 2010]. The resulting maps included only those areas that were subject to conferment, whereas the remaining areas were not included in the measurements, and therefore no 
real estate cadastre covering all of the land was established in the area of the former Russian annexation.

In the interwar period, no measurement work was undertaken to establish a cadastre for the whole area of the country. The maps were created for selected areas covered by the land reform and land consolidation. Work on the territory of the former Russian partition was carried out on the basis of the "Technical manual for performing measurement work related to the reconstruction of the agricultural system" [Regulation 1925].

Due to the lack of uniform system throughout the country (including the territories of the former Russian partition), it became necessary not so much to modernize the land records, as to establish them from scratch. The first legal steps towards it were taken after the end of the Second World War, when the Decree [1947] on the land and building cadastre was issued, which was intended to introduce a uniform land and building cadastre in the entire country, and yet it was repealed on the date of its issue. The legal act introducing uniform land records for the entire country only came with the Decree on the registration of land and buildings, which stated in Article 3 that (to quote): "Records cover all lands and buildings located in the area of the community, the settlement, or the city (...)" [Decree 1955].

Article 5 addresses the map for record purposes, which should cover the area of one registration unit, and should specify the following:

1. "the boundaries of land owned by individuals (...)".

Another legal act regarding the registration of land and buildings, which detailed the principles introduced in the above Decree [1955] was the Order [1969] by the Ministers of Agriculture and Municipal Economy regarding land registry. The Order introduced the premises for land registry that contained information about the owners, the limits of possession and the areas of the plots subjected to measurement. Issues regarding the ownership of these lands were regulated by the Act [1971] on the regulation of the ownership of farms.

\section{Measurement techniques used for the establishment of land records at the time}

The technical requirements for setting up geodetic measurement networks for establishing land records in the post-war period are specified in the technical instruction B-III, included in the "Detailed Measurement" provisions (Section B of the "Universal Regulations on the Country's Measurement") in force between 1949-1979 [Announcement 1949, Ordinance 1965].

Measurements of situational details were then made on the basis of the Technical Manual for land measurements of the State Agricultural Farms (Annex to Regulation No. 59 by the Ministry of Agriculture [1955]) and Technical Conditions for Creating a New Geodetic Base for Soil Classification (Annex to Regulation No. 271 by the Ministry of Agriculture [1956]). In 1962 the aforementioned regulations were replaced 
with "Technical instruction on the performance of geodetic works related to the surveillance and agricultural spatial planning and land registry in the areas of communities, settlements and cities not constituting districts" [Regulation 1962].

The geodetic measurement networks were established as multi-order polygonal traverses (orders I and II) forming networks connected to higher-order State geodetic networks - if such networks existed. If there were no link points, an independent triangulation network had to be established for areas exceeding 3000 ha in size. For areas smaller than 1000 ha, a network of independent technical polygonisation was established. The points of the geodetic network were stabilized depending on the class of the order: using stone columns, concrete poles without a base, or with a base (a stone slab, a drainage pipe, a bottle) and timber piles (Fig. 1).

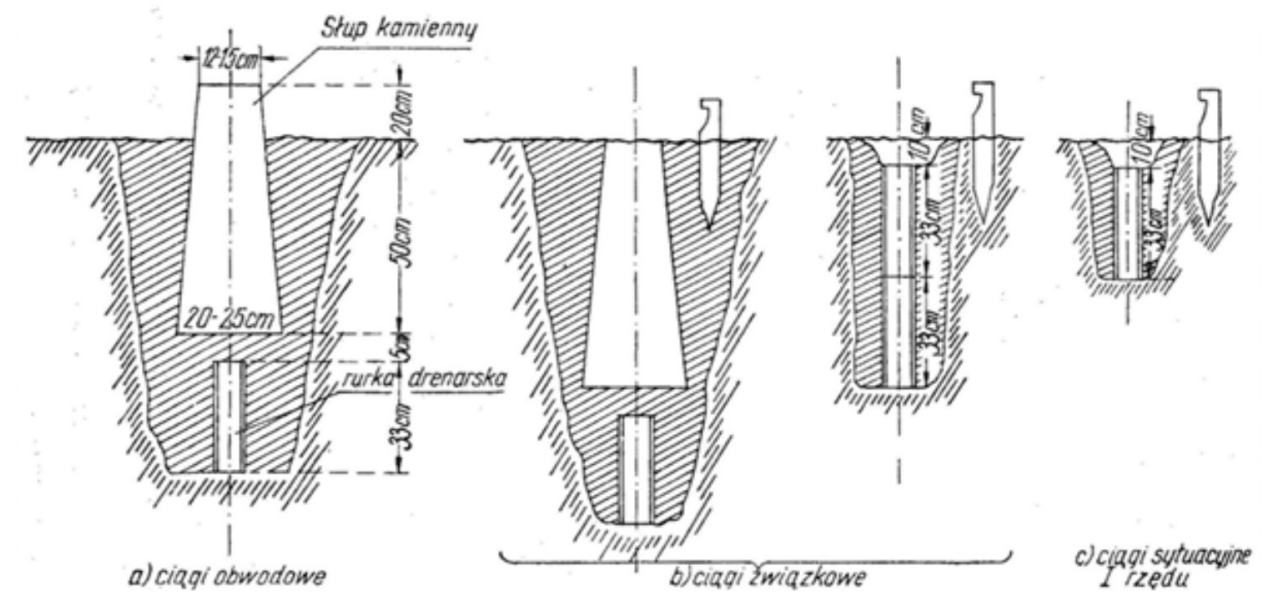

Source: Frelek [1964]

Fig. 1. Sample stabilisation of geodetic network points

In the areas where the boundaries of the land were measured directly in the field, a measuring network was usually established covering only this particular area or precinct. Common points lying at the boundaries of the precincts were included in the geodetic network orders in each precinct independently. Coordinates were calculated in local systems or in the coordinate reference system of 1942. Measurements of situational details were made using the orthogonal method or the interpolation method, which were used alternately - often on one measuring line (Fig. 2).

Pursuant to $₫ 44$ of the "Instruction..." [Regulation 1962], the land boundaries were measured according to the actual condition existing in the field during the measurement without delimitation, and therefore the established land records reported the actual condition, determined in accordance with the boundaries of use. This is important because the boundaries of real estate property thus determined led to the issue of the titles of land ownership, based on the Act [1971] on the regulation of farm ownership. 


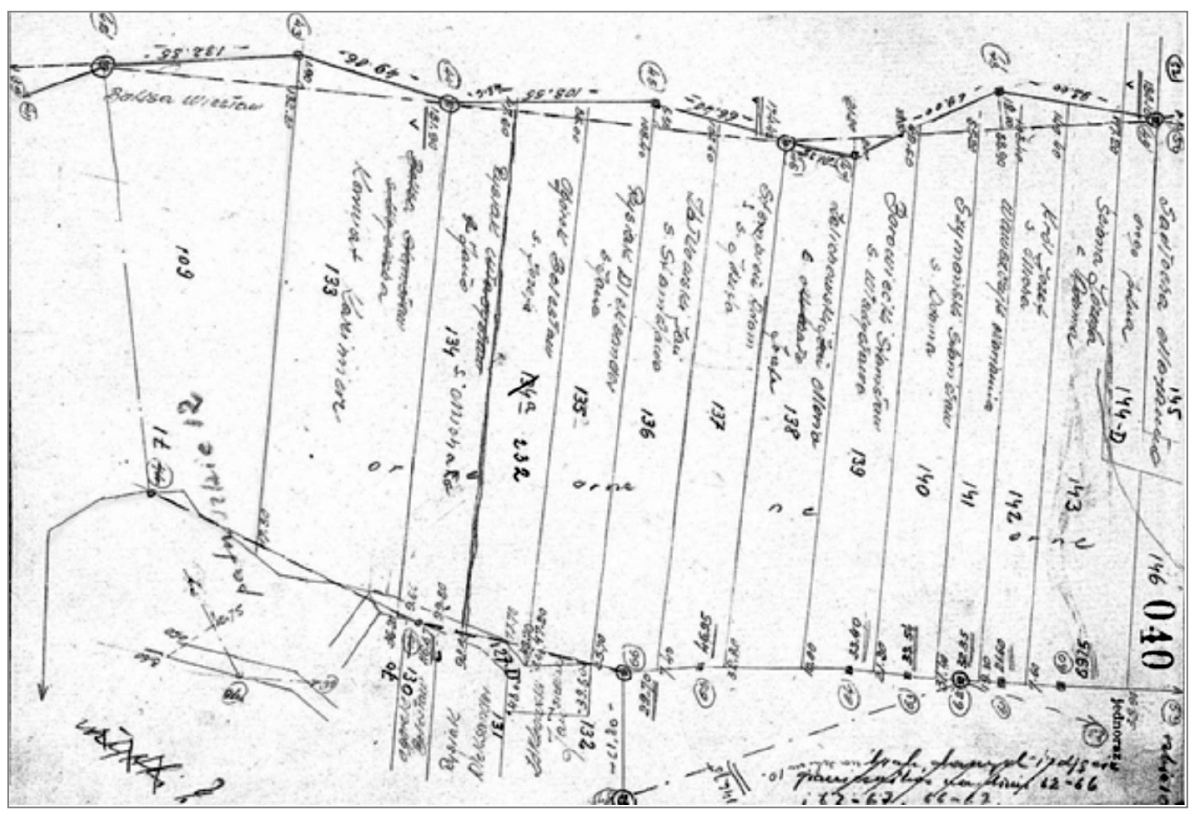

Source: technical report of land records establishment, Ciecierze precinct

Fig. 2. Fragment of a draft prepared during the establishment of land records

The correct interpretation of the method used at the time is of fundamental importance to the on-going work aimed at recreating the boundaries of the parcels measured at that time. Incorrect interpretation of the applied method may lead to erroneous determination of the location of breakpoints (corners) of plot boundaries in the field, and thus the creation of a border dispute, the resolution of which in the demarcation procedure is costly and time-consuming.

It should be noted that in many areas (precincts) no measurements were made for the breakpoints of plot boundaries based on the geodetic measurement network. The map of land records was based on photogrammetric foundations, from which information on the course of the boundaries of cadastral plots was obtained [Instruction 1962]. In the field, only measurement outlines of the plots were developed. In such cases, it is impossible to faithfully reconstruct the original state existing in the field (from the time of the establishment of land records), and therefore the current procedure for the determination (restoration) of boundary points disclosed in the land records is not applicable.

\section{Geodesic measurement networks - current condition and application possibilities}

The assortment of surveying works based on archival data from the establishment of land records is very broad [Regulation 2011]. The correctness of the determined coor- 
dinates of the breakpoints (corners) of plot boundaries adopted in the studies listed in this document depends primarily on the accuracy of calculating the coordinates of geodetic measurement network points, when establishing the land records. No less important is also the technical condition of the geodetic documentation, which is the basis for the reconstruction of the boundaries at the time (the state of preservation of field sketches, the readability of the measures placed in them, and thus the ability to calculate the coordinates of the breakpoints and course of the boundaries).

Regulation [2011] clearly defines the procedure to determine the coordinates of the breakpoints of plot boundaries, assuming that the geodetic measurement network points are physically preserved in the field, as stipulated in $\$ 30.1$ (to quote): “Geodetic situational measurements, aimed at resuming boundary marks or determining boundary breakpoints, are made using observational data defining the location of these marks or breakpoints based on the geodetic measurement network that was used to obtain the said data".

Unfortunately, a major part of the points of measurement control networks have not survived until this day. The credibility of the position of the preserved marks of the control network is also questionable, which is due to a number of reasons. In the case where the points of the measurement control network are not physically preserved in the field, the procedure should be in accordance with $\$ 30.2$. of the Regulation [2011] (to quote): "In the event if the measurement control network referred to in paragraph. 1 is not preserved, due to the destruction or displacement of its points or the inability to reproduce the control network, then geodetic situational measurements should be performed, aimed at resuming boundary marks or determining boundary breakpoints based on:

1) the topographic descriptions of these boundary breakpoints or

2) the coordinates of these boundary breakpoints after their prior harmonization by way of mathematical transformation with the reference system determined by the points of the horizontal geodetic control network and the measurement situational matrix".

Considering the two cases: the points of the measurement control network have been physically preserved in the field and have not been moved, or the measurement network points have not survived - because they have been displaced or damaged - in accordance with the provisions of $\$ 30.1$ of the Regulation [2011], it is necessary to find points in the field, and while using archival observations, recreate the state in the field, as registered at the time of establishing the land records.

An important technical task is the method of finding the points of the geodetic network. This can be done based on the topographic descriptions of these points. Unfortunately, any such descriptions are mostly out of date, as they were made many years earlier, in an area lacking the orientation details that would help finding the points. This problem is well illustrated by the example shown in Figure 3. Finding the point of the geodetic network can also be done on the basis of angular and linear measures, calculated in the polygonal traverses when these are established (Fig. 4). It should be noted, however, that such a possibility exists when we find at least two points and look for the next points in the traverse. A frequent impediment is the lack of the lines, 
because the traverses were established over half a century ago. Finding the points of the geodetic measurement network is also possible based on the coordinates in the current coordinate system. The issue of the origin of the coordinates of the measurement network remains problematic in this case.

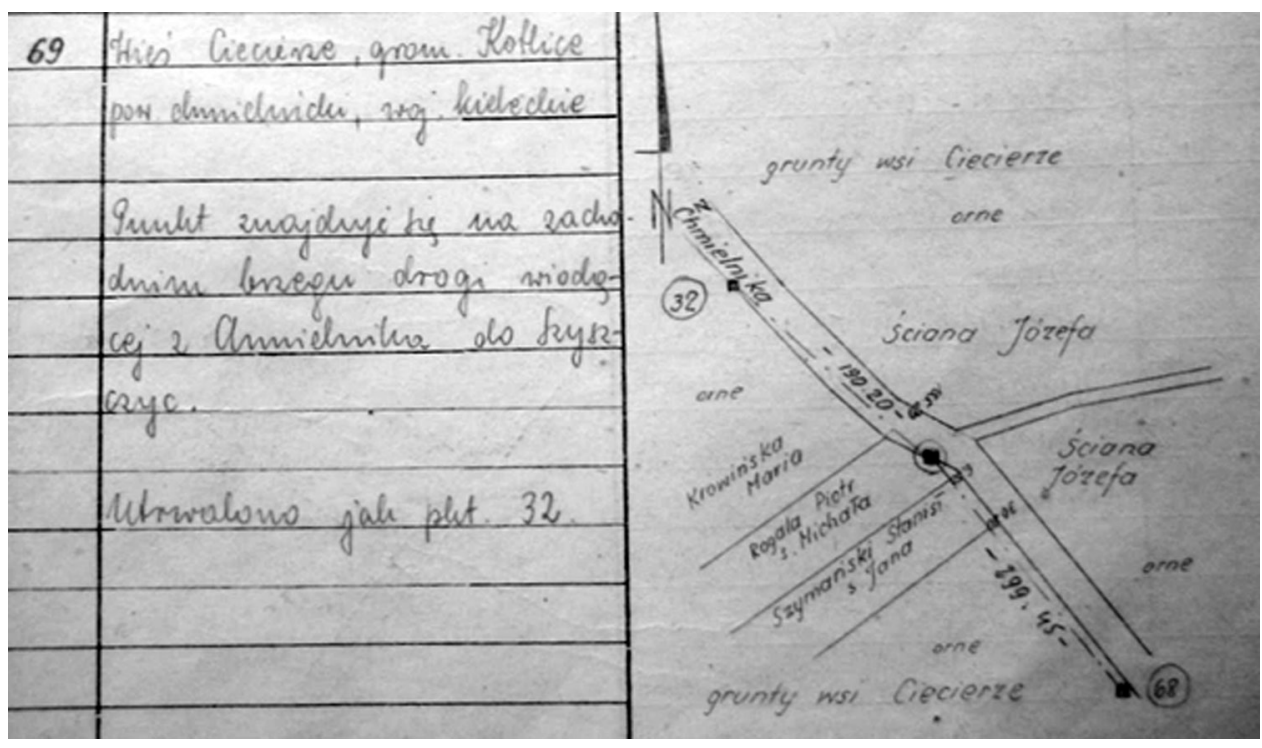

Source: technical report of land records establishment, Ciecierze precinct

Fig. 3. Sample topographic description of a point in a geodetic measurement matrix

Unfortunately, we cannot always be sure that the coordinates of the measurement network points from the PODGIK resources are correct and know whether they correspond to the actual location of the points in the field. The contractor receives lists from the geodetic network databank, including coordinates in the 2000 and 1965 layouts (Fig. 5).

The origin of the coordinates in the 1965 system is important - the points of the geodetic network were originally given in the 1942 layout or in the local layout. They were transformed (transferred) to the 1965 layout - for example, during the modernization of land records (the so-called phase II). Unfortunately, often the insufficient number of adjustment points and their unfavourable distribution resulted in discrepancies between the coordinates obtained as a result of the transformation and their original (actual) location in the field. When analysing archival studies related to the transformation of geodetic measurement networks, a number of errors related to the selection of adjustment points and numerical errors can be detected. This results in incorrect coordinates, which do not correspond to the actual position of the given point, being recorded in the PODGiK geodetic network databank. 


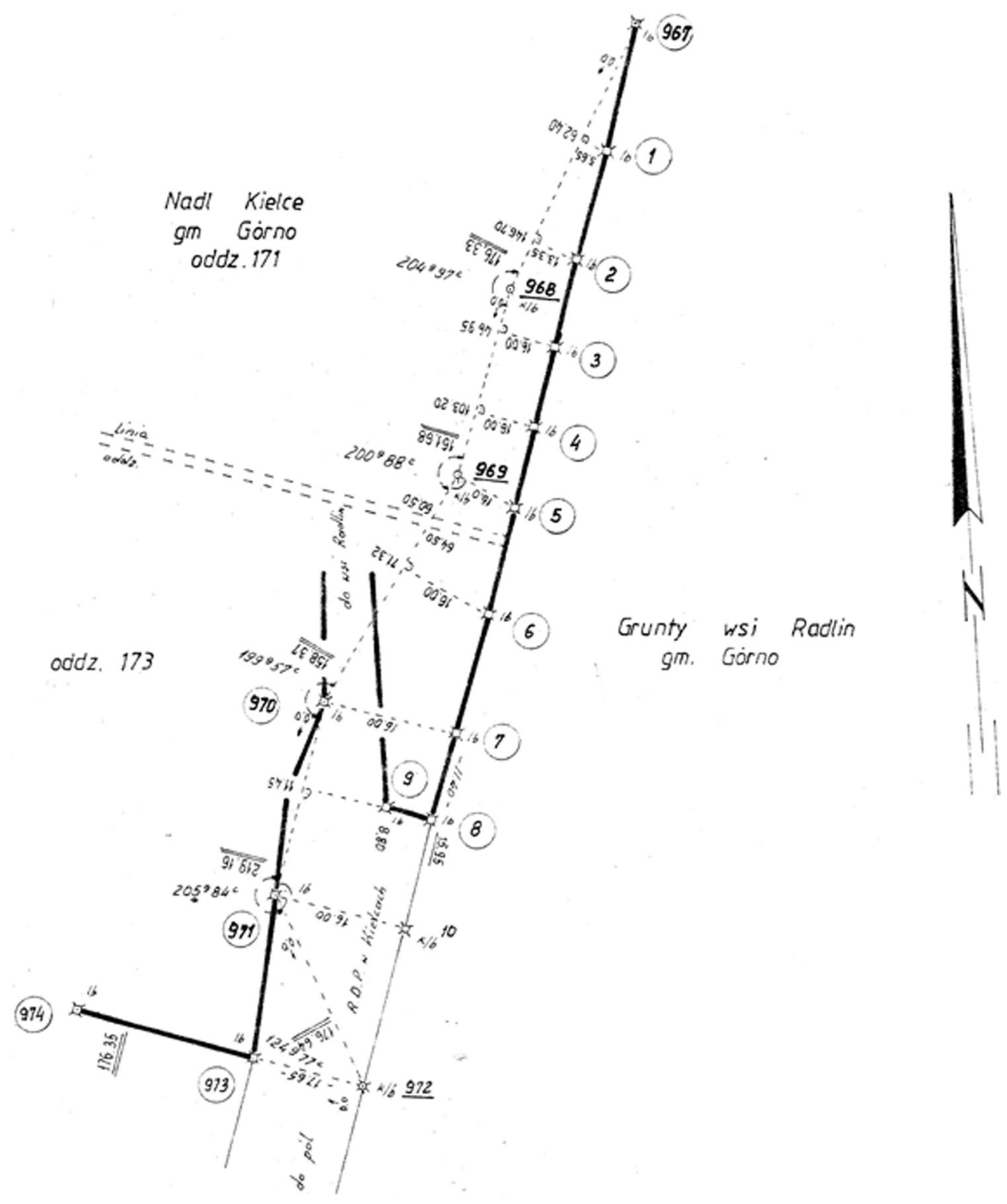

Source: technical report of land records establishment, Radlin precinct

Fig. 4. Draft of a geodetic measurement network at the border of the precincts

We often observe cases such as one described in $\$ 30.2$ of the Regulation [2011], that is, when the geodetic measurement network point is missing, damaged or displaced. In this case, we need to find the place where the geodetic network point was fixed, i.e. to perform the procedure described for the case where the point does exist. In the course 
of performing the procedure, the same problems may appear, especially when we try to find a point based on the coordinates from the databank of geodetic networks. The point is often located underground, and the question remains whether the point really has not been preserved or whether we were merely searching for in the wrong place. The problem, which so far remains unresolved, is the question of the reliability of the coordinates defining the measurement points gained from the PODGiK, and therefore the difficulty in determining the key issue - whether the coordinates are correct and the point has been shifted over the years, whether it has been destroyed, or else, whether the point has not been moved, but only the point's coordinates are given incorrectly.

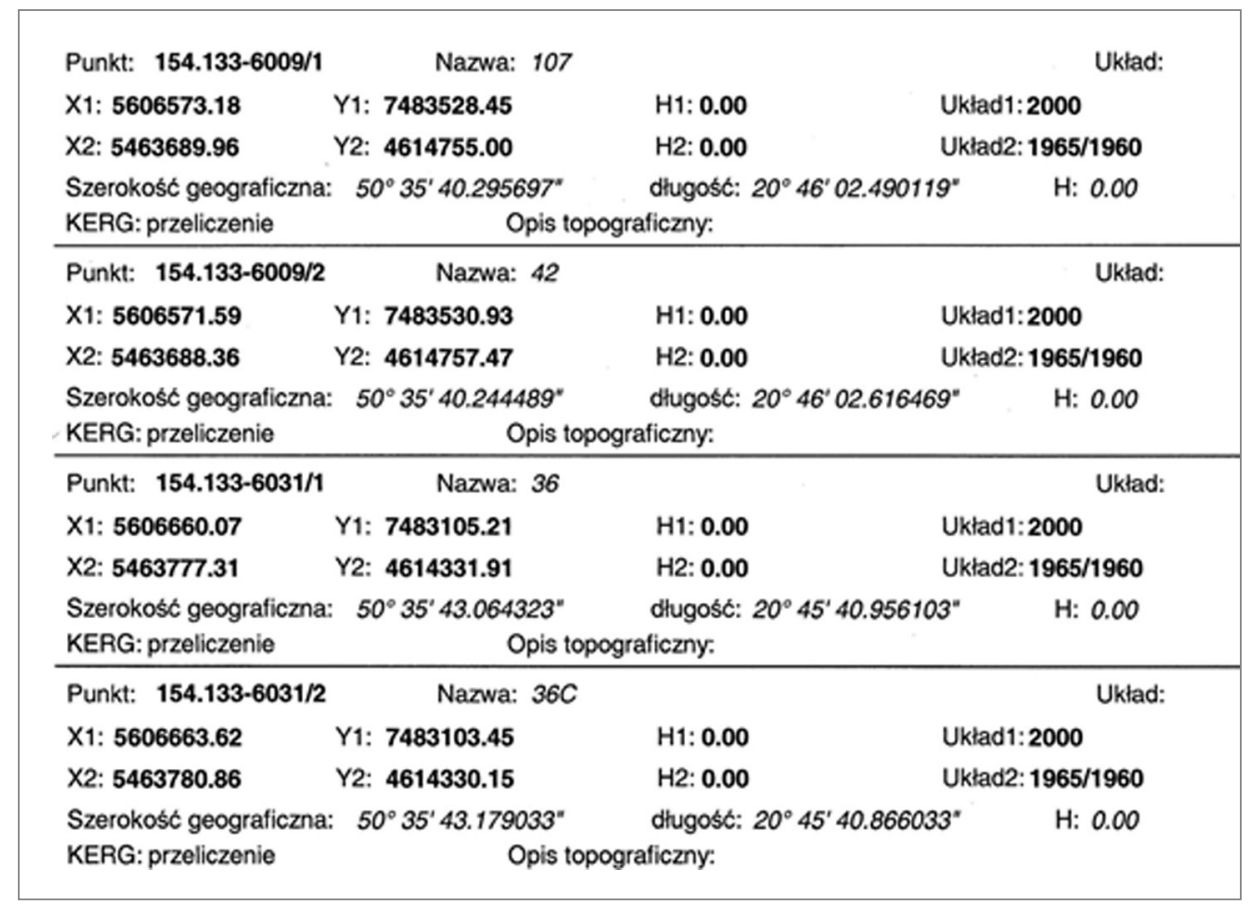

Fig. 5. Sample printout of the measurement matrix from the geodetic measurement network databank run by the PODGiK

6. Reliability of geodetic measurement network point location in the process of restoring the boundaries of cadastral plots

Current maps of land and building records (EGiB) are kept in numerical format (complete database of plots - parcels - for the given area or precinct) or in the form of a so-called hybrid map (fitted raster of the cadastral map, on which the boundaries of parcels are plotted, being the result of the individual, unit-specific studies for legal purposes). Numerical maps covering the whole cadastral precinct area were created 
over a dozen or so years on the basis of changing specifications. Some of these studies were preceded by analyses of the accuracy of the geodetic network points (measurement of points found in the field). In other cases, the studies were based on coordinates of geodetic measurement networks obtained as a result of mathematical transformations. Some of the plot boundaries were determined as a result of vectorization of fitted rasters of the cadastral map (Fig. 6). Lack of information on the method of calculating the coordinates of the points of the measuring network puts into question the credibility of the calculated coordinates of the breakpoints of the cadastral plot boundaries. This imposes the necessity to recalculate the coordinates of the boundary points in the preparation of individual reports, just as it is the cases where the numerical map had not been created.

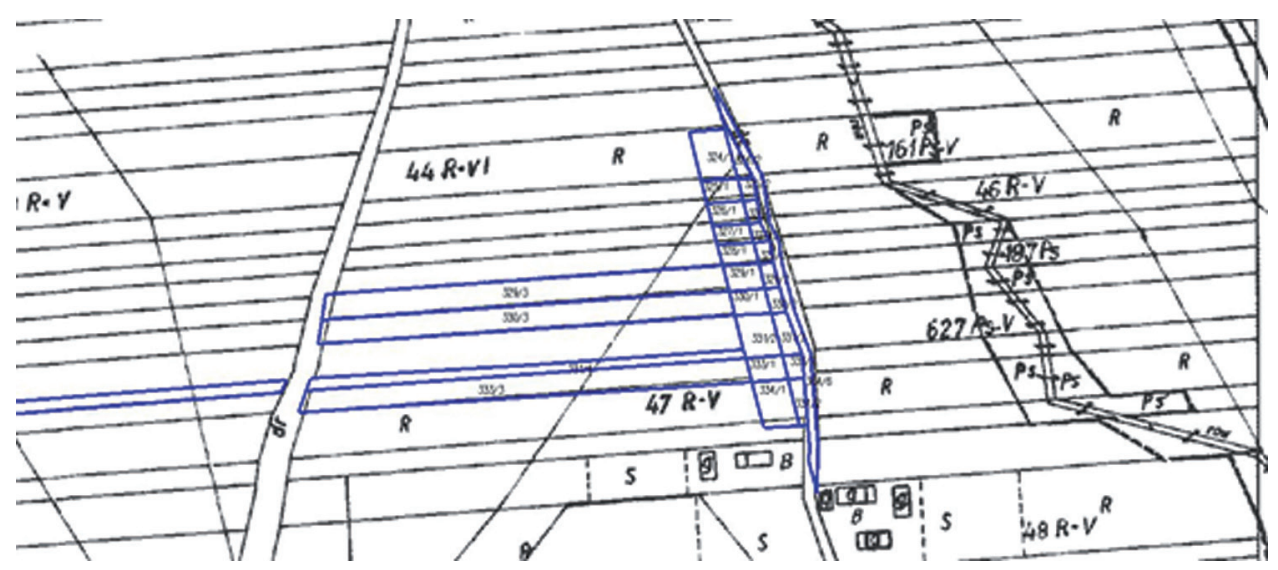

Source: map from the PODGiK resources, Bieliny precinct

Fig. 6. Sample merging of the land and building records map (raster map) with plotted single parcels in vector format

As it has already been mentioned, the most important problem when calculating the coordinates of the breakpoints of plot boundaries is the lack of reliable coordinates of the points of the geodetic measurement network. Such coordinates do not exist in the current 2000 PODGiK system. Each time during geodetic works regarding the boundaries of cadastral plots - that is, case by case - the verification of coordinates received from PODGiK is required by finding the surviving points of the geodetic measurement network in the field, and a control measurement thereof - provided that such coordinates have been previously calculated, of course. So far, practice has come down to constant control and searching for points in the field. There are several possibilities:

- the points have been found, and coordinates are sufficiently consistent, within acceptable limits; 
- the points have been found, but the measured coordinates do not match the coordinates from the PODGiK geodetic measurement networks databank;

- the points have been found, however, while some of the coordinates corresponds to the coordinates from the PODGiK databank, others exceed the acceptable discrepancies;

- some of the points have been found, and the coordinates agree with the coordinates from the PODGiK databank of geodetic measurement networks;

- some points have been found, and the coordinates do not match the coordinates from the PODGiK databank of geodetic measurement networks.

Hence, there are many possibilities, and this applies to cases where coordinates are available. Many more problems arise when there are no coordinate points of measurement networks available in the PODGiK resources, or when only observations are preserved. In this case, it becomes necessary to:

- find the surviving points and perform coordinate transformations from the local system to the current layout or

- find the surviving points, calculate the traverse or traverses that we are interested in, while treating the found points as links.

In the case of transformation, this situation raises a number of problems - finding properly positioned and distributed points in the field is often difficult or impossible. Points adopted for transformation are either unfavourably distributed or insufficient in number. In individual reports, coordinates of the points of the geodetic measurement network are adopted or calculated in a variety of ways (which may be more or less correct). The result is a situation where the coordinates of boundary points can be obtained in the procedure of establishing the boundaries (if the documentation shows the lack or insufficient quality of archival materials) or by finding geodetic points in the field and based on that, calculating the coordinates of the points forming the same boundary. In this manner, we receive two versions of the same boundary, obtained on the basis of various procedures (establishing boundaries and resuming boundary points), which of course is unacceptable. Such situations inevitably lead to border disputes, and arriving at a solution is time-consuming and costly.

\section{Discrepancies in the coordinates of geodetic measurement network points}

Testing the compliance between the coordinates of geodetic measurement networks has been carried out on several dozens of precincts in the Swiętokrzyskie region. The identification of the preserved points of individual polygonal traverses, combined with their control measurement based on the preserved archival data (coordinates of points and angular-linear measures), made it possible to identify irregularities in the scope of data gathered in the PODGiK database. On the basis of several selected cases, irregularities will be presented that have a significant impact on determining the originally intended boundaries of cadastral plots. 
Table 1. Discrepancies between coordinates of geodetic measurement network points: B1 and B2

\begin{tabular}{|c|c|c|c|c|c|c|c|}
\hline \multicolumn{8}{|c|}{ Polygonal traverse - B1 } \\
\hline \multicolumn{3}{|c|}{$\begin{array}{c}\text { Coordinates } \\
\text { measures using GPS RTN }\end{array}$} & \multicolumn{3}{|c|}{$\begin{array}{l}\text { Coordinates } \\
\text { from the PODGiK database }\end{array}$} & \multicolumn{2}{|c|}{$\begin{array}{l}\text { Difference } \\
\text { in coordinates }\end{array}$} \\
\hline Point No. & $X(\mathrm{~m})$ & $Y(\mathbf{m})$ & Point No. & $X(\mathbf{m})$ & $Y(\mathbf{m})$ & $d x(\mathbf{m})$ & $d y(\mathbf{m})$ \\
\hline $121 \mathrm{LP}$ & $\mathrm{xxxx} 032.09$ & $\mathrm{xxxx} 779.35$ & 121 & $\mathrm{xxxx} 032.35$ & xxxx780.62 & 0.26 & 1.27 \\
\hline $122 \mathrm{LP}$ & $\mathrm{xxxx} 054.54$ & xxxx699.56 & 122 & $\mathrm{xxxx} 054.77$ & $\mathrm{xxxx700.76}$ & 0.22 & 1.2 \\
\hline $123 \mathrm{LP}$ & $\mathrm{xxxx} 051.12$ & $\mathrm{xxxx} 562.81$ & 123 & $\mathrm{xxxx} 051.53$ & $\mathrm{xxxx} 563.89$ & 0.41 & 1.08 \\
\hline $124 \mathrm{LP}$ & $\mathrm{xxxx} 020.08$ & $\mathrm{xxxx} 546.86$ & 124 & $\mathrm{xxxx} 020.25$ & $\mathrm{xxxx} 547.97$ & 0.16 & 1.11 \\
\hline \multicolumn{8}{|c|}{ Polygonal traverse - B2 } \\
\hline \multicolumn{3}{|c|}{$\begin{array}{c}\text { Coordinates } \\
\text { measures using GPS RTN }\end{array}$} & \multicolumn{3}{|c|}{$\begin{array}{l}\text { Coordinates } \\
\text { from the PODGiK database }\end{array}$} & \multicolumn{2}{|c|}{$\begin{array}{l}\text { Difference } \\
\text { in coordinates }\end{array}$} \\
\hline Point No. & $X(\mathbf{m})$ & $Y(\mathrm{~m})$ & Point No. & $X(\mathbf{m})$ & $Y(\mathbf{m})$ & $d x(\mathbf{m})$ & $d y(\mathbf{m})$ \\
\hline $137 \mathrm{LP}$ & $\mathrm{xxxx} 163.55$ & xxxx692.93 & 137 & $\mathrm{xxxx} 163.50$ & xxxx692.62 & -0.05 & -0.31 \\
\hline 138LP & $\operatorname{xxxx} 113.88$ & $\operatorname{xxxx} 737.86$ & 138 & xxxx114.15 & $\mathrm{xxxx} 737.45$ & 0.26 & -0.41 \\
\hline 139LP & $\mathrm{xxxx} 088.37$ & $\mathrm{xxxx} 787.54$ & 139 & $\mathrm{xxxx} 088.43$ & $\mathrm{xxxx787.22}$ & 0.06 & -0.32 \\
\hline
\end{tabular}

Table 2. Discrepancies between coordinates of P1 geodetic measurement network points

\begin{tabular}{|c|c|c|c|c|c|c|}
\hline \multicolumn{7}{|c|}{ Polygonal traverse - P1 } \\
\hline \multirow{2}{*}{ Point No. } & \multicolumn{2}{|c|}{$\begin{array}{c}\text { Coordinates } \\
\text { measures using GPS RTN }\end{array}$} & \multicolumn{2}{|c|}{$\begin{array}{l}\text { Coordinates } \\
\text { from the PODGiK database }\end{array}$} & \multicolumn{2}{|c|}{$\begin{array}{c}\text { Difference } \\
\text { in coordinates }\end{array}$} \\
\hline & $X(\mathrm{~m})$ & $Y(\mathbf{m})$ & $X(\mathrm{~m})$ & $Y(\mathbf{m})$ & $d x(\mathbf{m})$ & $d y(\mathbf{m})$ \\
\hline 309LP & xxxx998.14 & $\mathrm{xxxx} 561.7$ & xxxx997.994 & $\mathrm{xxxx} 561.581$ & -0.146 & -0.119 \\
\hline $310 \mathrm{LP}$ & $\mathrm{xxxx} 051.34$ & $\mathrm{xxxx} 525.5$ & $\mathrm{xxxx} 051.227$ & $\mathrm{xxxx} 525.313$ & -0.113 & -0.187 \\
\hline $311 \mathrm{LP}$ & xxxx998.15 & $\mathrm{xxxx} 462.34$ & $\mathrm{xxxx} 003.172$ & xxxx458.696 & 5.022 & -3.644 \\
\hline $313 \mathrm{LP}$ & $\mathrm{xxxx} 043.75$ & $\mathrm{xxxx} 268.23$ & $\mathrm{xxxx} 047.153$ & $\mathrm{xxxx270.227}$ & 3.403 & 1.997 \\
\hline
\end{tabular}

The first of the analysed cases concerns two independent polygon traverses in the same area of the Gnojno municipality (in Busko-Zdrój district). On the basis of the received data, the points of these measurement networks were identified, and a control measurement was carried out. The results obtained in Table 1 show that there are irregularities in the scope of data from the PODGiK database. The discrepancies that were determined between the coordinates of the tested points obtained from the PODGiK database and the new measurement ranged between a few and several dozen centimetres for the $X$ and $Y$ coordinates. 
A slightly different case of irregularities was found within the Pierzchnica municipality (in Kielce district). Based on the measurements carried out using archival angular-linear measures, it was found that two points of the examined polygonal traverse (311 and 312) changed their original position, and that the coordinates from the PODGiK database do not correspond to the data obtained from the control measurement Table 2).

The occurrence of irregularities also applies to other cases, such as when points are incorrectly transformed to the new coordinate system. The results are included in Table 3.

Table 3. Data discrepancies resulting from incorrect transformation of point coordinates to the 1965 layout

\begin{tabular}{|c|c|c|c|c|c|c|c|}
\hline \multicolumn{3}{|c|}{$\begin{array}{l}\text { Result of the control transformation } \\
\text { of point coordinates to the } 1965 \text { layout }\end{array}$} & \multicolumn{3}{|c|}{$\begin{array}{l}\text { Result of the transformation of point } \\
\text { coordinates to the } 1965 \text { layout } \\
\text { - the PODGiK database }\end{array}$} & \multicolumn{2}{|c|}{$\begin{array}{l}\text { Difference } \\
\text { in coordinates }\end{array}$} \\
\hline Point No. & $X(\mathbf{m})$ & $Y(\mathbf{m})$ & Point No. & $X(\mathbf{m})$ & $Y(\mathbf{m})$ & $d x(\mathbf{m})$ & $d y(\mathbf{m})$ \\
\hline $1 / 65$ & $\operatorname{xxxx} 069.30$ & $\operatorname{xxxx} 777.20$ & $1 / 65 / 84$ & $\mathrm{xxxx} 068.22$ & $\operatorname{xxxx} 779.53$ & -1.08 & 2.33 \\
\hline $2 / 65$ & $\mathrm{xxxx} 182.21$ & $\mathrm{xxxx} 628.35$ & $2 / 65 / 84$ & xxxx181.22 & $\mathrm{xxxx} 630.52$ & -0.99 & 2.17 \\
\hline $3 / 65$ & $\mathrm{xxxx} 151.20$ & $\mathrm{xxxx} 278.46$ & $3 / 65 / 84$ & $\mathrm{xxxx} 150.24$ & $\mathrm{xxxx} 280.26$ & -0.96 & 1.80 \\
\hline $55 / 65$ & $\mathrm{xxxx} 370.92$ & $\mathrm{xxxx} 491.25$ & $55 / 65 / 84$ & $\mathrm{xxxx} 369.31$ & $\mathrm{xxxx} 494.35$ & -1.61 & 3.10 \\
\hline $56 / 65$ & $\mathrm{xxxx} 283.27$ & $\mathrm{xxxx} 453.55$ & $56 / 65 / 84$ & $\mathrm{xxxx} 281.73$ & $\mathrm{xxxx} 456.61$ & -1.54 & 3.06 \\
\hline $57 / 65$ & $\mathrm{xxxx} 142.42$ & $\mathrm{xxxx} 390.73$ & $57 / 65 / 84$ & xxxx140.99 & $\mathrm{xxxx} 393.72$ & -1.43 & 2.99 \\
\hline $58 / 65$ & $\mathrm{xxxx} 159.07$ & xxxx196.48 & $58 / 65 / 84$ & $\mathrm{xxxx} 157.65$ & xxxx199.27 & -1.42 & 2.79 \\
\hline $62 / 65$ & $\mathrm{xxxx} 228.17$ & $\mathrm{xxxx} 039.49$ & $62 / 65 / 84$ & $\mathrm{xxxx} 226.81$ & $\mathrm{xxxx} 042.10$ & -1.36 & 2.61 \\
\hline $66 / 65$ & $\mathrm{xxxx} 321.35$ & $\mathrm{xxxx} 930.45$ & $66 / 65 / 84$ & $\mathrm{xxxx} 320.07$ & xxxx932.94 & -1.28 & 2.49 \\
\hline $67 / 65$ & $\mathrm{xxxx} 268.52$ & $\mathrm{xxxx} 898.41$ & $67 / 65 / 84$ & $x x x x 267.28$ & xxxx900.87 & -1.24 & 2.46 \\
\hline $68 / 65$ & $\mathrm{xxxx} 335.04$ & $\mathrm{xxxx} 495.35$ & $68 / 65 / 84$ & $\mathrm{xxxx} 334.21$ & $\mathrm{xxxx} 497.41$ & -0.83 & 2.06 \\
\hline $69 / 65$ & $\mathrm{xxxx} 590.33$ & $\mathrm{xxxx338.77}$ & $69 / 65 / 84$ & $\mathrm{xxxx} 589.76$ & $\mathrm{xxxx339.13}$ & -0.57 & 0.36 \\
\hline
\end{tabular}

It is particularly interesting to compare the coordinates for the same points of the measurement network, revealed in duplicate in the PODGiK database of geodetic measurement networks (Table 4). Discrepancies between these coordinates reach several dozen centimetres for some points.

Each of the examples quoted above poses serious difficulties related to geodetic work and requires additional operations related to the analysis of the output data. It seems that the problem can be solved through specific activities including inventory of the existing geodetic network points in particular areas combined with the analysis 
of their current condition, and precise alignment of the entire matrix using archived measurement data (angles and length) and the existing points already measured contemporarily, which as a result analyses will be considered as fixed (permanent) points. Thus obtained coordinates of the measurement network points, with the given accuracy characteristics, could be considered correct. Then if the contractors use the calculated coordinates of the geodetic network points, this would ensure the consistency of measurements over the whole area of the cadastral precinct.

Table 4. Data discrepancies for the same points of the geodetic measurement networks - in the PODGiK geodetic networks database

\begin{tabular}{|c|c|c|c|c|c|c|c|}
\hline \multicolumn{3}{|c|}{ KERG - A } & \multicolumn{3}{|c|}{ KERG - B } & \multicolumn{2}{|c|}{$\begin{array}{l}\text { Difference in } \\
\text { coordinates }\end{array}$} \\
\hline Point No. & $X(\mathbf{m})$ & $Y(\mathbf{m})$ & Point No. & $X(\mathbf{m})$ & $Y(\mathbf{m})$ & $d x(\mathbf{m})$ & $d y(\mathbf{m})$ \\
\hline 1 & $\mathrm{xxxx} 380.71$ & $\mathrm{xxxx} 139.62$ & 21 & $\mathrm{xxxx} 381.12$ & $\mathrm{xxxx} 139.56$ & 0.41 & -0.06 \\
\hline 2 & $\mathrm{xxxx} 357.71$ & $\mathrm{xxxx} 304.81$ & 22 & $\mathrm{xxxx} 358.11$ & $\mathrm{xxxx} 304.74$ & 0.40 & -0.07 \\
\hline 3 & xxxx326.41 & $\mathrm{xxxx} 530.99$ & 23 & $\mathrm{xxxx} 326.86$ & $\mathrm{xxxx} 530.61$ & 0.45 & -0.38 \\
\hline 4 & $\mathrm{xxxx} 303.82$ & xxxx692.98 & 24 & $\mathrm{xxxx} 304.25$ & $\mathrm{xxxx} 692.53$ & 0.43 & -0.45 \\
\hline 5 & $\mathrm{xxxx} 473.31$ & $\mathrm{xxxx} 830.76$ & 25 & $\mathrm{xxxx} 473.54$ & xxxx830.20 & 0.23 & -0.56 \\
\hline 6 & xxxx827.87 & $\mathrm{xxxx} 978.75$ & 26 & $\mathrm{xxxx} 827.72$ & $\mathrm{xxxx} 978.41$ & -0.15 & -0.34 \\
\hline 7 & xxxx659.09 & $\mathrm{xxxx} 889.56$ & 27 & $\mathrm{xxxx} 659.05$ & $\mathrm{xxxx} 889.00$ & -0.04 & -0.56 \\
\hline 8 & xxxx198.75 & xxxx116.14 & 28 & xxxx198.58 & xxxx115.77 & -0.17 & -0.37 \\
\hline 9 & $\mathrm{xxxx} 345.33$ & $\mathrm{xxxx} 176.13$ & 29 & $\mathrm{xxxx} 345.14$ & $\mathrm{xxxx} 175.86$ & -0.19 & -0.27 \\
\hline 10 & xxxx996.46 & $\mathrm{xxxx} 031.75$ & 30 & xxxx996.32 & $\mathrm{xxxx} 031.27$ & -0.14 & -0.48 \\
\hline
\end{tabular}

\section{Proposed solutions}

As results from the analyses we have conducted, the lack of unambiguous coordinates of the geodetic measurement network poses a number of problems. Data on the coordinates of boundary points transferred to the PODiK database are often unreliable. On the basis of such data, legal reports and master maps are developed, partly concerning cadastral plots. Even the numerical elaborations of the database of plots for the entire precincts are not free of errors and, as a result, they are not credible.

The solution to the problem seems to be an in-depth analysis of the data on geodetic measurement networks included in the land records establishment reports, and field work related to the inventory of existing points together with their measurement for the entire geodetic network established for the given area (precinct). The results that the analysis should produce include: 
- statements covering the numbers of the measurement network points and measurement data (angles and lengths) from the archival documentation;

- results of the point inventory - coordinates measured with the required accuracy, using the GPS RTN method (and if it is not possible to use this method, then the GNSS static positioning method);

- calculation of polygon traverses linked to the existing and currently measured geodetic network points in the field;

- analysis aimed at identifying the points that did not remain fixed - as they were moved, dug up, and so forth;

- simultaneous exact alignment of the entire matrix as an angular-linear network in accordance with $\$ 18.1$. of the Regulation [2011] (observational data on the geodetic measurement network is aligned using the least-squares method in a single-line network system).

Obviously, in this way we will not obtain coordinates that meet the current standards regarding the accuracy of the point location $\left(m_{p}\right.$ value of not more than $\left.0.10 \mathrm{~m}\right)$, because the measurement of the geodetic network during its establishment did not meet today's standards specified in the Regulation [2011] - mainly due to low accuracy of distance measurement. At this point, it is important whether the analysed measurements met the accuracy requirements of their time, contained in the Announcement [1949]. The requirements can be found in the annexes to the instruction B-III, which distinguished four categories of terrain difficulty (from A to D), with different accuracy requirements assigned to each.

In the adjustment process, the whole should be treated as a single-line network. In such case, the found points that remained fixed and were measured by means of GPS, can be treated as links. In the alignment process, the coordinates of the measured points can be assumed as error-free or alternatively we can assume the uncertainty of these points while specifying location errors $\left(m_{x}, m_{y}\right)$. Thus obtained, the list of coordinates of the geodetic measurement network points covers all points along with the accuracy characteristics of their coordinates.

Such coordinates should be treated as the best data available, and based on these, the coordinates of the breakpoints of cadastral plots' boundaries should be calculated. Adopting the correct archival coordinates of geodetic control networks in the currently binding coordinate system 2000 will increase the quality of surveying works performed by surveyors, resulting in individual reports for legal purposes.

\section{References}

Cymerman R., Goraj S., Nowak A., Ofierska E., Przybyłowski K., Surowiec S. 1987. Ewidencja gruntów. PWN, Warszawa.

Dekret z dnia 24 września 1947 r. o katastrze gruntowym i budynkowym (Dz.U. z 1947 r. Nr 61, poz. 344).

Dekret z dnia 2 lutego 1955 r. o ewidencji gruntów i budynków (Dz.U. z 1955 r. Nr 6, poz. 32). 
Frelek M. i in. 1964. Urządzenia rolne. Polskie Przedsiębiorstwo Wydawnictw Kartograficznych (PPWK), Warszawa.

Hanus P. 2007. Wykorzystanie dokumentacji byłego katastru austriackiego do regulacji stanu prawnego nieruchomości. Geomatics and Environmental Engineering, 1, 4, 127-138.

Hycner R. 2004. Podstawy katastru. Wydawnictwo AGH, Kraków.

Instrukcja C-III „Opracowanie mapy zasadniczej w skali $1: 5000$ na podkładzie fotogrametrycznym" zatwierdzona przez Prezesa Głównego Urzędu Geodezji i Kartografii dnia 18.07.1962 r.

Mika M. 2010. Historia katastru polskiego. Infrastruktura i Ekologia Terenów Wiejskich, 6, Polska Akademia Nauk, Oddział w Krakowie, 75-85.

Obwieszczenie Prezesa Głównego Urzędu Pomiarów Kraju z 27 lipca 1949 r. o wydaniu „Instrukcji B-III - Poligonizacja techniczna" (M.P. z 1949 r. Nr 54, poz. 732). http://www.heltechnic.pl/info_Instrukcja_techniczna_B-III - cite_note-2

Przewięźlikowska A., Skotnicki K. 2001. Wykorzystanie pruskich i niemieckich oraz rosyjskich materiałów katastralnych dla potrzeb współczesnych, wybranych prac geodezyjnych i zagadnień prawnych. Geodezja, 7, 1.

Rozporządzenie Ministra Reform Rolnych z dnia 13 lutego 1925 r. o stosowaniu instrukcji technicznej do wykonywania prac pomiarowych, związanych z przebudową ustroju rolnego.

Rozporządzenie Ministra Spraw Wewnętrznych i Administracji z dnia 9 listopada 2011 r. w sprawie standardów technicznych wykonywania geodezyjnych pomiarów sytuacyjnych i wysokościowych oraz opracowywania i przekazywania wyników tych pomiarów do państwowego zasobu geodezyjnego i kartograficznego (Dz. U. z 2011 r. Nr 263, poz. 1572).

Rozporządzenie Rady Ministrów z dnia 15 października 2012 r. w sprawie państwowego systemu odniesień przestrzennych (Dz. U. z 2012 r., poz. 1247).

Uchwała Prezydium Rządu nr 16/S/53 z dnia 31 marca 1953 r. w sprawie założenia jednolitej państwowej sieci geodezyjnej i opracowania mapy podstawowej państwa.

Uchwała Sejmu Ustawodawczego z dnia 10 lipca 1919 r. w przedmiocie zasad reformy rolnej (Druk Nr 839).

Ukaz carski „O urządzeniu włościan w Królestwie Polskim” z 2 marca (19 lutego) 1864 r. (Dziennik Praw nr 187, tom 62, Warszawa 1864).

Ustawa z dnia 26 października 1971 r. o uregulowaniu własności gospodarstw rolnych (Dz.U. z 1971 r. Nr 27, poz. 250).

Wilkowski W. 2005. Historia katastru w Polsce. Przegląd Geodezyjny, 7, Warszawa.

Wolski J. 2001. Kataster podatku gruntowego na ziemiach polskich - rys historyczny oraz geodezyjne i kartograficzne zasady sporządzania. Przegląd Geograficzny, 73, 1-2, 107-131.

Wytyczne techniczne i organizacyjne modernizacji i prowadzenia ewidencji gruntów w miastach, wprowadzone przez Prezesa Głównego Urzędu Geodezji i Kartografii dnia 01.03.1979 r.

Zarządzenie nr 59 Ministerstwa Rolnictwa z dnia 19 kwietnia 1955 roku nr UR 9-7-3/55 (Biuletyn Ministerstwa Rolnictwa z roku 1956 Nr 15, poz. 90).

Zarządzenie nr 271 Ministerstwa Rolnictwa z dnia 7 grudnia 1956 r. Nr UR.GR.10/26/56 .

Zarządzenie nr 47 Ministra Rolnictwa z dnia 10 marca 1962 r. Nr Ur.GE.380-24/62 w sprawie wprowadzenia „Instrukcji technicznej o wykonywaniu robót geodezyjnych w resorcie rolnictwa".

Zarządzenie nr 26 Prezesa Głównego Urzędu Geodezji i Kartografii z dnia 28 czerwca 1965 r. (Dz. Urz. GUGiK Nr 6, poz. 29).

Zarządzenie Ministrów Rolnictwa i Gospodarki Komunalnej z dnia 20 lutego 1969 r. w sprawie ewidencji gruntów (M.P. z 1969 r. Nr 11, poz. 98). 
Mgr inż. Mateusz Śmigielski

Dr hab. inż. Jacek M. Pijanowski

Uniwersytet Rolniczy w Krakowie

Katedra Geodezji Rolnej, Katastru i Fotogrametrii

ul. Balicka 253a, 30-198 Kraków

e-mail: jacek.pijanowski@urk.edu.pl

Dr inż. Jacek Gniadek

Uniwersytet Rolniczy w Krakowie

Katedra Geodezji Rolnej, Katastru i Fotogrametrii

ul. Balicka 253a, 30-198 Kraków

e-mail: jacek.gniadek@urk.edu.pl 